Review

\title{
Alcoholism and Alternative Splicing of Candidate Genes
}

\section{Toshikazu Sasabe and Shoichi Ishiura*}

Department of Life Sciences, Graduate School of Arts and Sciences, the University of Tokyo, 3-8-1, Komaba, Meguro-ku, Tokyo, 153-8902, Japan; E-Mail: cc087707@ mail.ecc.u-tokyo.ac.jp

* Author to whom correspondence should be addressed; E-Mail: cishiura@ mail.ecc.u-tokyo.ac.jp; Tel.: +81-3-5454-6739; Fax: +81-3-5454-6739.

Received: 26 February 2010; in revised form: 21 March 2010 / Accepted: 23 March 2010 /

Published: 30 March 2010

\begin{abstract}
Gene expression studies have shown that expression patterns of several genes have changed during the development of alcoholism. Gene expression is regulated not only at the level of transcription but also through alternative splicing of pre-mRNA. In this review, we discuss some of the evidence suggesting that alternative splicing of candidate genes such as DRD2 (encoding dopamine D2 receptor) may form the basis of the mechanisms underlying the pathophysiology of alcoholism. These reports suggest that aberrant expression of splice variants affects alcohol sensitivities, and alcohol consumption also regulates alternative splicing. Thus, investigations of alternative splicing are essential for understanding the molecular events underlying the development of alcoholism.
\end{abstract}

Keywords: alcoholism; alternative splicing; dopamine; NMDA; GABA; voltage-gated calcium channel; neurexin

\section{Introduction}

Alternative pre-mRNA splicing makes a large contribution to proteomic diversity. In alternative splicing, various potential splice sites of the pre-mRNA from a single gene are used in various combinations that lead to the translation of several functionally distinct protein isoforms from several different mRNA species. In the brain, the regulation of splice variants modulates protein functions, which can ultimately affect behavior such as alcohol dependence. Alcohol dependence (AD) is a common, chronic and relapsing disorder with an estimated heritability of 40-60\% [1]. Family and twin 
studies have shown that genetic factors contribute to the risk of $\mathrm{AD}$ and genetic mapping studies have identified numerous genes associated with this risk [2-5]. Most of these genes affect ethanol metabolism, ethanol preference, or diverse brain systems, such as the reward system [6,7].

Alterations in expression have been shown to be involved in producing neuroadaptative changes following chronic ethanol consumption [8,9]. A key question in $\mathrm{AD}$ is the transition from controlled to compulsive drinking, and development of dependence may be related not only to gene expression modulated through transcriptional regulation but also through alternative splicing of genes, which may produce functionally distinct isoforms.

In this review, we describe several examples of alternative splicing which may affect ethanol preference and consumption. We propose that alternative spliced forms may be important to the development of alcoholism.

\section{Ethanol-Associated Genes}

\subsection{The D2 Dopamine Receptor}

The mesolimbic dopamine system plays an important role in the rewarding and reinforcing effect of drugs on the brain $[10,11]$. It is thought to play a similar role in the rewarding effect of ethanol, as ethanol administration induces the release of dopamine in the nucleus accumbens [12].

Of the five dopamine receptor subtypes, the D2 receptor subtype (DRD2) has been extensively studied in alcoholism [13-23]. In rats, a decreased DRD2 density is associated with a preference for ethanol [14], and transient overexpression in the nucleus accumbens attenuated ethanol preference [15]. In humans, positron emission tomography studies have revealed decreased DRD2 availability in the striatum of alcoholics [16,17], and support a hypothesis that a high DRD2 level in the striatum is a protective factor against alcoholism [18]. Moreover, polymorphisms of the DRD2 gene are linked with an altered risk of alcoholism [19-23].

Alternative splicing generates two DRD2 isoforms, D2S and D2L. These isoforms differ in that D2L has a sixth exon, which encodes its third cytoplasmic region [24]. Although the two isoforms are co-expressed, D2S is preferentially expressed in dopaminergic neurons in presynaptic regions, such as the substantia nigra and the hypothalamus, and D2L predominates in postsynaptic regions, such as the striatum and the pituitary gland [25-27]. In recombinant cell lines and mouse brains, D2L has a lower affinity for dopamine than D2S [24,28,29]. DRD2 is coupled with $\mathrm{G}_{\alpha \mathrm{i}}$, an adenylyl cyclase-inhibiting $\mathrm{G}$ protein, and because $\mathrm{G}_{\alpha \mathrm{i}}$ binding is mediated by the third cytoplasmic loop of DRD2, D2S and D2L have different specificities for the subtypes of $\mathrm{G}_{\alpha \mathrm{i}}[30-32]$.

The D2S and D2L isoforms also differ in their effects on downstream protein phosphorylation. D2S has been suggested to decrease the phosphorylation of tyrosine hydroxylase, and D2L has been suggested to increase the dopamine D1 receptor (DRD1)-induced phosphorylation of DARPP-32 (dopamine- and cAMP-regulated phosphoprotein of $32 \mathrm{kDa}$ ) [33]. In addition, D2S and D2L have been reported to differ in the levels of their accumulation in the endoplasmic reticulum (ER) [34] and in the regulation of their sequestration by $G$ protein-coupled receptor kinases and $\beta$-arrestins [35]. Furthermore, although both D2L and D2S participate in the presynaptic inhibition of $\gamma$-aminobutyric acid (GABA) release in the striatum, the presynaptic inhibition of glutamate release is preferentially 
modulated by D2S [36]. D2L-deficient mice showed distinct pharmacological behavior from DRD2-deficient mice and wild-type mice, suggesting that the D2L splice variant has different functions from D2S in vivo [27,29,37,38].

Ethanol affects the alternative splicing of DRD2 pre-mRNA [39]. Ethanol administration to rats has been reported to increase the D2L/D2S receptor ratio in the pituitary gland, and this effect was reproduced in primary cultures of pituitary cells treated with ethanol. We separately confirmed this effect of ethanol on DRD2 splicing in the human neuroblastoma cell line SH-SY5Y (unpublished data). In pituitary cells, ethanol not only alters DRD2 splicing, but also diminishes the inhibition of prolactin secretion by the DRD2-specific analog bromocriptine [39]. These facts suggest that ethanol suppresses dopamine-induced responses by altering DRD2 splicing. Allelic expression analysis in human postmortem brain tissues and functional magnetic resonance imaging measurements in healthy humans have shown that $\mathrm{T}$ carriers of single-nucleotide polymorphisms (SNPs) rs2283265 and rs 1076560, both of which flank DRD2 exon 6, express relatively fewer D2S receptors and exhibit worse performance during working tasks [40]. We have demonstrated that $\mathrm{T}$ carriers of SNP rs 1076560 have a higher alcoholism risk [22].

These findings suggest that individuals possessing fewer D2S receptors, such as T carriers, have less intense responses to dopamine (like ethanol-preferring rats) and therefore prefer to drink alcohol. Furthermore, this tendency is enhanced through a positive feedback loop in which ethanol administration decreases the number of $\mathrm{D} 2 \mathrm{~S}$ receptors.

\subsection{The N-Methyl-D-aspartate (NMDA) Receptor NR1 Subunit}

The NMDA (N-methyl-D-aspartate) receptor, an ionotropic glutamate receptor in the central nervous system, is a pivotal target of ethanol [41]. Ethanol attenuates NMDA receptor function in a dose-related fashion in vitro [42,43]. The NMDA receptor is a heteromeric protein composed of at least one NR1 subunit and at least one NR2 subunit. Ethanol appears to bind to the NR1 subunit in a hydrophobic pocket associated with the third transmembrane domain [44]. Ligand binding to the NMDA receptor is up-regulated in rodents chronically treated with ethanol [43,45-48] and in postmortem cortical tissue from alcoholic patients [49,50]. This up-regulation of the NMDA receptor reduces ethanol sensitivity and therefore contributes to ethanol tolerance [51].

The NMDA receptor is a cation channel with high $\mathrm{Ca}^{2+}$ permeability. The NR1 subunit is essential for receptor-channel function, and the NR2 subunit modulates the properties of the channel [52]. The recently identified NMDA subunit NR3 decreases NMDA-induced current and $\mathrm{Ca}^{2+}$ permeability $[53,54]$.

The NR1 subunit has eight isoforms generated by alternative splicing of exons 5, 21, and 22. The NR1-a variant lacks exon 5, which encodes the N1 splice cassette that lies in the extracellular N-terminal domain of the NR1 subunit, and NR1-b includes exon 5. Exons 21 and 22 encode the C-terminal splice cassettes $\mathrm{C} 1$ and $\mathrm{C} 2$, respectively, and are part of the intracellular domain of the NR1 subunit. NR1 splice variants lacking exon 22 contain a C2' cassette as an additional cassette at their C-terminal end (see Figure 1 in reference [55]). These splice variants vary considerably in their properties and are differentially localized in adult and developing animals [56,57]. 
These alternative cassettes modulate the properties of the NMDA receptor. The presence of the N1 cassette, which forms a surface loop with structural similarities to polyamines, decreases the affinities of the receptor for NMDA and glutamate [58]. It potentiates the receptor function by relieving the tonic proton inhibition [59] and voltage-independent zinc inhibition [60]. It also accelerates the deactivation time course of NMDA responses when NR1 is co-expressed with the NR2B (but not NR2A) subunit [61,62]. The first $\mathrm{C} 1$ cassette includes a calmodulin-binding site, and binding of calmodulin to NR1 inhibits NMDA channel activity [63-65]. Although the $\mathrm{C} 1$ cassette also has protein kinase $\mathrm{C}$ (PKC) phosphorylation sites, and phosphorylation affects the subcellular distribution of NR1 [66], PKC potentiation of the NMDA receptor probably does not occur through direct phosphorylation of the receptor but, rather, through phosphorylation of receptor-associated proteins [67,68].

Interestingly, the NR1 isoforms have differential sensitivities to ethanol-induced inhibition. When expressed singly in Xenopus oocytes, the sensitivity of the NR1-1b, NR1-2b, NR1-1a, and NR1-2a isoforms to ethanol follows the order NR1-1b > NR1-2b > NR1-1a > NR1-2a [69]. In contrast, when all eight NR1 isoforms are co-expressed in various combinations with one of the four NR2 subtypes in human embryonic kidney 293 cells, the sensitivity depends on the combination. For example, the NR1-3b/NR2C, NR1-3b/NR2D, and NR1-4b/NR2C pairs are most weakly inhibited by ethanol (approximately $15 \%$ inhibition), and the NR1-2b/NR2C pair is most strongly inhibited by ethanol (>50\% inhibition) [70].

Several reports have described the modulation of expression of specific NR1 isoforms by ethanol [54,57,71-77]. Some of the reported findings appear to be inconsistent. For example, although mRNA ratio of NR1 splice variants containing exon 5 to those lacking exon 5 (+E5/-E5) decreases in the cortex of rats exposed to ethanol vapor [72] and in mouse fetal cortical neurons treated with ethanol [73], it increases in the striatum of rats chronically treated with ethanol solution [77]. Raeder et al. [77] postulated that this inconsistency arises from differences in the dose, duration of consumption, and route of administration of alcohol. In addition, the effects of ethanol on the expression of NR1 isoforms might differ in each brain region.

Thus, despite this inconsistency, ethanol consumption may increase NR1 isoforms that are weakly inhibited by ethanol. Together with up-regulation of the NMDA receptors [37,39-44], this regulation of splice variants should contribute to the reduction of ethanol sensitivity and the induction of ethanol tolerance.

\subsection{The $G A B A_{A}$ Receptor $\gamma 2$ Subunit}

The ionotropic $\mathrm{GABA}_{\mathrm{A}}$ receptor, a GABA-gated chloride channel receptor, is involved in the diverse effects of ethanol on the central nervous system [78]. The ionotropic $\mathrm{GABA}_{\mathrm{A}}$ receptor and the metabotropic $\mathrm{GABA}_{\mathrm{B}}$ receptor mediate the inhibition of neuronal excitability by GABA. The majority of fast synaptic inhibition is mediated through the $\mathrm{GABA}_{\mathrm{A}}$ receptor. Acute ethanol administration enhances $\mathrm{GABA}_{\mathrm{A}}$ receptor activity at intoxicating concentrations, whereas chronic ethanol administration decreases GABAergic function [79-81]. Together with up-regulation of the NMDA receptor, this down-regulation of the $\mathrm{GABA}_{\mathrm{A}}$ receptor contributes to ethanol tolerance, dependence, and withdrawal hyperexcitability. Ethanol directly binds to a pocket located between transmembrane domains of the $\mathrm{GABA}_{\mathrm{A}}$ receptor, inducing conformational changes [82-84]. Dopaminergic neurons in 
the midbrain are activated not only directly through ethanol exposure, but also indirectly through the down-regulation of GABAergic inhibitory transmission to these neurons [85-87].

The $\mathrm{GABA}_{\mathrm{A}}$ receptor is a heteromer of five subunits. Almost all GABA $\mathrm{A}$ receptors consist of two $\alpha$, two $\beta$, and one $\gamma$ subunit; the most frequent combinations are $\alpha 1 \beta 2 \gamma 2, \alpha 2 \beta 3 \gamma 2$, and $\alpha 3 \beta 3 \gamma 2$, which comprise approximately 60,15 , and $10 \%$ of $\mathrm{GABA}_{\mathrm{A}}$ receptor proteins, respectively [88]. Genes for these subunits form clusters on several chromosomal regions; 4p13-q11 ( $\alpha 2, \alpha 4, \beta 1, \gamma 1), 5 q 34-q 35(\alpha 1$, $\alpha 6, \beta 2, \gamma 2), 15 q 11-q 13(\alpha 5, \beta 3, \gamma 3)$, and Xq28 ( $\alpha 3, \beta 4, \varepsilon 1)$. Mice with knockouts of these genes generally do not exhibit alcohol-preferring behaviors [78]. Moreover, agonists of the $\mathrm{GABA}_{\mathrm{A}}$ receptor enhance alcohol-drinking behavior, and antagonists inhibit it [89-91]. These results illustrate the importance of the $\mathrm{GABA}_{\mathrm{A}}$ receptor in alcohol consumption.

The $\mathrm{GABA}_{\mathrm{A}}$ receptor $\alpha 2$ subunit has four major isoforms differing in their combinations of two alternative exons (exon 1A versus exon $1 \mathrm{~B}$ and exon 9A versus exon 10) and two minor isoforms lacking exon 4 or exon 8 [92]. Two haplotypes of the $\alpha 2$ subunit gene (GABRA2) have been reported to be significant risk factors for $\mathrm{AD}$, although this conclusion is inconsistent with several other studies [93]. Some non-coding variations in the GABRA2 gene have been found to be associated with AD [94]. Because several SNPs are located in exon 8, exon 9, or in the introns flanking these exons, one can speculate that these SNPs affect the alternative splicing of these exons.

The $\gamma 2$ subunit has two splice variants, one long $(\gamma 2 \mathrm{~L})$ and one short $(\gamma 2 \mathrm{~S})$. The $\gamma 2 \mathrm{~L}$ variant differs from the $\gamma 2 \mathrm{~S}$ variant in that it has an eight-amino-acid insert in the intracellular loop between transmembrane domains three and four. Intriguingly, in rats, chronic intermittent ethanol administration decreases the hippocampal ratio of $\gamma 2 \mathrm{~L} / \gamma 2 \mathrm{~S}$ [95]. The $\gamma 2 \mathrm{~L}$ insert modulates $\mathrm{GABA}_{\mathrm{A}}$ receptor function; it contains a serine residue that is phosphorylated by $\mathrm{PKC}$, reducing the amplitudes of GABA-activated currents [96]. In addition, when $\gamma 2 \mathrm{~L}$ is co-expressed with $\alpha$ and $\beta$ subunits in Xenopus oocytes, only the $\gamma 2 \mathrm{~L}$ subunit is sensitive to the reinforcing effect of ethanol [97]. It also exhibits accelerated deactivation in human embryonic kidney 293 cells [98]. Knockout mice lacking this insert $(\gamma 2 \mathrm{~L}-\mathrm{KO})$ appear to be unaffected in their electrophysiological and behavioral response to ethanol [99], contrary to the different effects of the isoforms mentioned above. On the other hand, $\gamma 2 \mathrm{~L}$ accumulates at inhibitory postsynaptic sites more effectively than $\gamma 2 \mathrm{~S}$, and this accumulation is facilitated by PKC phosphorylation of the $\gamma 2 \mathrm{~L}$ insert [100]. Meier and Grantyn argue that $\gamma 2 \mathrm{~S}$ functions sufficiently in $\gamma 2 \mathrm{~L}-\mathrm{KO}$ mice only because it does not have to compete with $\gamma 2 \mathrm{~L}$ for gephyrin binding sites and that it actually differs from $\gamma 2 \mathrm{~L}$ in its properties [100]. Moreover, expression of the $\gamma 2 \mathrm{~L}$ and $\alpha 1$ subunits increases during development; they are the predominant isoforms in mature GABAergic synapses [101]. Thus, a reduced $\gamma 2 \mathrm{~L} / \gamma 2 \mathrm{~S}$ ratio probably interferes with the maturation of inhibitory synapses and may indicate a higher risk of alcoholism.

\subsection{N-Type and L-type Voltage-gated $\mathrm{Ca}^{2+}$ Channels}

Opening of voltage-gated $\mathrm{Ca}^{2+}$ channels depends on the membrane potential. The resulting influx of $\mathrm{Ca}^{2+}$ into the cell triggers various events including neurotransmitter release. $\mathrm{Ca}^{2+}$ channels are composed of at least three subunits $\left(\alpha_{1}, \alpha_{2} \delta\right.$, and $\beta$ ). The $\alpha_{1}$ subunit is critical for $\mathrm{Ca}^{2+}$ channel functions, and its various subtypes confer functional diversity. 
The N-type $\mathrm{Ca}^{2+}$ channel is involved in the molecular and behavioral effects of ethanol. Acute ethanol exposure inhibits the activity of the N-type channel in PC12 cells [102], whereas chronic ethanol exposure increases the density of N-type channels and therefore increases depolarizationevoked $\mathrm{Ca}^{2+}$ influx [103]. In addition, mice lacking N-type channels exhibit reduced voluntary ethanol consumption and preference [104]. Treatment with the mixed N-type and T-type channel antagonist NP078585 has a phenotypic effect similar to that of ethanol [105].

The $\alpha_{1}$ subunit of the $\mathrm{N}$-type channel is $\alpha_{1} 2.2$, which has three alternative exons (exon 18a, exon $24 \mathrm{a}$, and exon 31a). The splice variants of these exons exhibit functionally diverse $\mathrm{Ca}^{2+}$ signaling in neurons. Exon 31a encodes two amino acids in the IVS3-IVS4 linker, altering the rate of channel opening and the voltage dependence of channel activation [106,107]. Chronic ethanol exposure decreases expression of the variant lacking exon 31a and increases the N-type current [108], suggesting that ethanol facilitates the functions of $\mathrm{N}$-type $\mathrm{Ca}^{2+}$ channels by altering the composition of splice variants.

The L-type channel is also involved in ethanol consumption. Acute ethanol exposure inhibits the L-type channel, whereas chronic ethanol exposure induces a rise in the voltage-gated $\mathrm{Ca}^{2+}$ current, an effect thought to reflect up-regulation of the L-type channel [109,110]. In addition, L-type channel antagonists decrease ethanol withdrawal symptoms and ethanol self-administration in rodents [111,112].

The $\alpha_{1 \mathrm{C}}$ subunit of the L-type channel has two splice variants, $\alpha_{1 \mathrm{C}-1}$ and $\alpha_{1 \mathrm{C}-2}$. These variants differ in that $\alpha_{1 \mathrm{C}-1}$ has three additional amino acid residues between domains II and III and 28 additional residues in the S3 segment in domain IV. They are differentially expressed in rat brain [113], but little is known about their differences in function. Ethanol treatment in PC12 cells has been reported to increase the level of $\alpha_{1 \mathrm{C}}$ protein in a PKC $\delta$ activity-dependent manner, whereas it increases the mRNA level of $\alpha_{1 \mathrm{C}-1}$, but not $\alpha_{1 \mathrm{C}-2}$, independent of $\operatorname{PKC} \delta$ [114]. These results indicate that ethanol up-regulates the L-type channel by increasing expression of the $\alpha_{1 \mathrm{C}-1}$ splice variant, in addition to PKC $\delta$-dependent and post-transcriptional regulation.

Ethanol consumption appears to alter the ratios of splice variants, thereby up-regulating $\mathrm{N}$ - and L-type calcium channels. This up-regulation appears to induce the neuronal hyperexcitability observed during ethanol withdrawal.

\subsection{Large-Conductance Calcium- and Voltage-Activated Potassium Channels (BK)}

BK channels are large-conductance calcium- and voltage-activated potassium channels. $\mathrm{K}^{+}$currents carried by BK channels participate in repolarization and hyperpolarization of action potentials, setting neuron firing properties [115]. BK channels consist of $\alpha$ core and $\beta$ auxiliary subunits. The $\alpha$ core subunit forms a ion-selective pore, a voltage-sensing module, and $\mathrm{Ca}^{2+}$-sensing module important for activation of the channel [116].

The activity of BK channels is modified by clinical doses of ethanol. Ethanol exposure potentiates BK activity in cell-free membranes and a cultured explant from rat posterior pituitary gland $[117,118]$. And BK channels in pituitary tumor (GH3) cells are also activated by ethanol [119]. This potentiation of BK channels in pituitary cells may contribute to the regulation of hormone secretion. Additionally, in a subgroup of primary sensory neurons in rat dorsal root ganglia, the BK potentiation by ethanol 
reduces neuronal excitability, and therefore, may underlie analgesic action in the peripheral nervous system [120]. Conversely, BK channels in arterial smooth muscle are inhibited by ethanol $[121,122]$. This ethanol-induced inhibition of BK channels may be a mechanism underlying contraction of vascular smooth muscle. And protracted ethanol exposure decreases ethanol sensitivity and the number of functional BK channels by cellular internalization, resulting in the tolerance to ethanol $[118,123]$.

The response and adaptation of BK channels to ethanol is modulated by the phosphorylation state of the channel protein [124], membrane lipid environment [125-127], and the composition of $\beta$ auxiliary subunits [123,128]. Moreover, altered expression of splice variants encoding the $\alpha$ core subunit is an underlying mechanism for the ethanol tolerance of BK channels [129]. Pietrzykowski and colleagues reported that, in the supraoptic nucleus and the striatal neurons, brief ethanol exposure decreased the splice variants of BK channels that are highly sensitive to ethanol. This down-regulation of alternatively spliced BK variants is caused by selective degradation of pre-existing mRNA, not by the regulation of alternative splicing. Ethanol exposure increases the expression of a miRNA (miR-9) that binds to 3'UTR sequence specific to the ethanol-sensitive splice variants, and therefore, enhances the degradation of these splice variants. And this molecular tolerance of BK channels to ethanol may contribute to the behavioral adaptation to ethanol.

\subsection{Neurexin-3}

In addition to modulating neurotransmitter receptors and ion channels, ethanol has been reported to inhibit cell-cell adhesion [130] and neurite outgrowth mediated by the L1 cell adhesion molecule (L1CAM) [131]. Ethanol directly binds to L1CAM at a critical domain interface [132] and disrupts its signaling cascade [133], suggesting that cell adhesion molecules are targets of ethanol.

The neuronal proteins known as neurexins function as cell adhesion molecules at presynaptic sites with extracellular binding partners, such as neuroligins, dystroglycan, and neurexophilins [134]. Neurexins modulate postsynaptic differentiation and receptor clustering [135] and perform an essential role in $\mathrm{Ca}^{2+}$-triggered neurotransmitter release by modulating voltage-dependent $\mathrm{Ca}^{2+}$ channels [136-138]. The gene for one of the neurexin family proteins, neurexin-3, is associated with nicotine dependence [139,140], opioid dependence [141], and poly-substance abuse [142], and cocaine exposure increases neurexin-3 expression in the globus pallidus of mice [143]. Moreover, neurexin-3 is expressed in neurons projecting to brain regions involved in addictive behaviors, such as the nucleus accumbens and the striatum [144] (http://www.brain-map.org/).

Neurexin genes have two distinct promoters from which longer forms ( $\alpha$-neurexins) and shorter forms ( $\beta$-neurexins) are transcribed. In addition, $\alpha$-neurexins have five alternative splice sites (splice sites 1-5) and $\beta$-neurexins have two (splice sites 4 and 5). In this way, an enormously diverse range of neurexin proteins are generated from each neurexin gene, and this diversity modulates synaptic functions [145]. For example, alternative splicing at splice site 4 modulates the binding affinity and specificity for neuroligins [146].

The splice site producing the greatest variety of proteins is splice site 5 of neurexin-3, which includes three exons (exons 22, 23, and 24). Exon 23 is very important because its inclusion confers solubility on neurexin-3 isoforms, and the transcripts lacking this exon encode transmembrane isoforms. SNP rs8019381, which is in the intronic sequence adjacent to the donor splice site of exon 23, 
is strongly associated with alcohol dependence and forms a haplotype block with rs760288 and rs2293847 [147]. Furthermore, T allele carriers of rs8019381 express fewer soluble isoforms lacking exon 23. Therefore, this polymorphism might increase the risk of alcoholism by affecting the alternative splicing of exon 23 and modulating the synaptic function of neurexin-3.

\section{Concluding Remarks}

Ethanol consumption can modulate not only the level of total transcripts of multiple genes, but also the ratio of their splice variants. Because splice variants have different functions, the altered expression of splice variants can ultimately affect behavior such as alcohol dependence. Indeed, as mentioned in this review, splice variants of DRD2 may affect ethanol preference by modulating dopamine sensitivity. And lower ethanol-sensitive splice variants of NMDA receptor, $\mathrm{GABA}_{\mathrm{A}}$ receptor, and ion channels contribute to ethanol tolerance. In addition, splice variants of $\mathrm{GABA}_{\mathrm{A}}$ receptor, voltage-gated $\mathrm{Ca}^{2+}$ channels, and neurexin-3 possibly contribute to withdrawal symptoms by inducing neuronal hyperexcitability. Furthermore, these propensities for ethanol can enhance ethanol consumption in turn. We propose this positive feedback as a mechanism underlying the development of alcoholism. Moreover, among candidate genes mentioned above, DRD2 and neurexin-3 have polymorphisms that are associated with both the risk of alcoholism and the expression ratio of splice variants. Therefore, polymorphisms without amino acid alteration in multiple candidate genes probably increase the risk of alcoholism by modulating the expression of alternatively spliced variants.

Many intriguing questions remain to be answered, such as how ethanol affects the splicing machinery. The oxidative stress induced in ethanol metabolism might be a factor; ethanol consumption results in the production of reactive oxygen species by the mitochondrial electron transport chain, cytochrome P450 2E1, and activated phagocytes [148], and chemical stresses are known to affect the splicing of specific pre-mRNAs [149].

Another question concerns the genome-wide ethanol-associated changes in alternative splicing. Ethanol-associated splice variants have thus far been investigated only for specific genes, not for the entire genome. For a genome-wide study, next generation sequencing is a useful screening tool for detecting both the altered expression of splice variants and alcoholism-associated polymorphisms. And a custom microarray such as the one generated by Johnson and colleagues [150] is also useful for studies of alternative splicing in multifactorial disorders including alcoholism.

\section{References and Notes}

1. McGue, M. Phenotyping alcoholism. Alcohol Clin. Exp. Res. 1999, 23, 757-758.

2. Crabbe, J.C.; Phillips, T.J.; Harris, R.A.; Arends, M.A.; Koob, G.F. Alcohol-related genes: contributions from studies with genetically engineered mice. Addict. Biol. 2006, 11, 195-269.

3. Mayfield, R.D.; Harris, R.A.; Schuckit, M.A. Genetic factors influencing alcohol dependence. $B r$. J. Pharmacol. 2008, 154, 275-287.

4. Gelernter, J.; Kranzler, H.R. Genetics of alcohol dependence. Hum. Genet. 2009, 126, 91-99.

5. Kalsi, G.; Prescott, C.A.; Kendler, K.S.; Riley, B.P. Unraveling the molecular mechanisms of alcohol dependence. Trends Genet. 2009, 25, 49-55. 
6. Mulligan, M.K.; Ponomarev, I.; Hitzemann, R. .; Belknap, J.K.; Tabakoff, B.; Harris, R.A.; Crabbe, J.C.; Blednov, Y.A.; Grahame, N.J.; Phillips, T.J.; Finn, D.A.; Hoffman, P.L.; Iyer, V.R.; Koob, G.F.; Bergeson, S.E. Toward understanding the genetics of alcohol drinking through transcriptome meta-analysis. Proc. Natl. Acad. Sci. U.S.A. 2006, 103, 6368-6373.

7. Hodgkinson, C.A.; Yuan, Q.; Xu, K.; Shen, P.H.; Heinz, E.; Lobos, E.A.; Binder, E.B.; Cubells, J.; Ehlers, C.L.; Gelernter, J.; Mann, J.; Riley, B.; Roy, A.; Tabakoff, B.; Todd, R.D.; Zhou, Z.; Goldman, D. Addictions biology: haplotype-based analysis for 130 candidate genes on a single array. Alcohol Alcohol. 2008, 43, 505-515.

8. $\quad$ Liu, J.; Lewohl, J.M.; Harris, R.A.; Iyer, V.R.; Dodd, P.R.; Randall, P.K.; Mayfield, R.D. Patterns of gene expression in the frontal cortex discriminate alcoholic from nonalcoholic individuals. Neuropsychopharmacology 2006, 31, 1574-1582.

9. Kerns, R.T.; Ravindranathan, A.; Hassan, S.; Cage, M.P.; York, T.; Sikela, J.M.; Williams, R.W.; Miles, M.F. Ethanol-responsive brain region expression networks: implications for behavioral responses to acute ethanol in DBA/2J versus C57BL/6J mice. J. Neurosci. 2005, 25, 2255-2266.

10. Tupala, E.; Tiihonen, J. Dopamine and alcoholism: neurobiological basis of ethanol abuse. Prog. Neuropsychopharmacol. Biol. Psychiatry 2004, 28, 1221-1247.

11. Di Chiara, G.; Bassareo, V. Reward system and addiction: what dopamine does and doesn't do. Curr. Opin. Pharmacol. 2007, 7, 69-76.

12. Yim, H.J.; Schallert, T.; Randall, P.K.; Gonzales, R.A. Comparison of local and systemic ethanol effects on extracellular dopamine concentration in rat nucleus accumbens by microdialysis. Alcohol Clin. Exp. Res. 1998, 22, 367-374.

13. Tupala, E.; Tiihonen J. Dopamine and alcoholism: neurobiological basis of ethanol abuse. Prog. Neuropsychopharmacol. Biol. Psychiatry 2004, 28, 1221-1247.

14. McBride, W.J.; Chernet, E.; Dyr, W.; Lumeng, L.; Li, T.K. Densities of dopamine D2 receptors are reduced in CNS regions of alcohol-preferring P rats. Alcohol 1993, 10, 387-390.

15. Thanos, P.K.; Taintor, N.B.; Rivera, S.N.; Umegaki, H.; Ikari, H.; Roth, G.; Ingram, D.K.; Hitzemann, R.; Fowler, J.S.; Gatley, S.J.; Wang, G.J.; Volkow, N.D. DRD2 gene transfer into the nucleus accumbens core of the alcohol preferring and nonpreferring rats attenuates alcohol drinking. Alcohol Clin. Exp. Res. 2004, 28, 720-728.

16. Hietala, J.; West, C.; Syvalahti, E.; Nagren, K.; Lehikoinen, P.; Sonninen, P.; Ruotsalainen, U. Striatal D2 dopamine receptor binding characteristics in vivo in patients with alcohol dependence. Psychopharmacology (Berl) 1994, 116, 285-290.

17. Volkow, N.D.; Wang, G.J.; Fowler, J.S.; Logan, J.; Hitzemann, R.; Ding, Y.S.; Pappas, N.; Shea, C.; Piscani, K. Decreases in dopamine receptors but not in dopamine transporters in alcoholics. Alcohol Clin. Exp. Res. 1996, 20, 1594-1598.

18. Volkow, N.D.; Wang, G.J.; Begleiter, H.; Porjesz, B.; Fowler, J.S.; Telang, F.; Wong, C.; Ma, Y.; Logan, J.; Goldstein, R.; Alexoff, D.; Thanos, P.K. High levels of dopamine D2 receptors in unaffected members of alcoholic families: possible protective factors. Arch. Gen. Psychiatry 2006, 63, 999-1008. 
19. Blum, K.; Noble, E.P.; Sheridan, P.J.; Montgomery, A.; Ritchie, T.; Jagadeeswaran, P.; Nogami, H.; Briggs, A.H.; Cohn, J.B. Allelic association of human dopamine D2 receptor gene in alcoholism. JAMA 1990, 263, 2055-2060.

20. Parsian, A.; Todd, R.D.; Devor, E.J.; O'Malley, K.L.; Suarez, B.K.; Reich, T.; Cloninger, C.R. Alcoholism and alleles of the human D2 dopamine receptor locus. Studies of association and linkage. Arch. Gen. Psychiatry. 1991, 48, 655-663.

21. Noble, E.P. The D2 dopamine receptor gene: a review of association studies in alcoholism and phenotypes. Alcohol 1998, 16, 33-45.

22. Sasabe, T.; Furukawa, A.; Matsusita, S.; Higuchi, S.; Ishiura, S. Association analysis of the dopamine receptor D2 (DRD2) SNP rs1076560 in alcoholic patients. Neurosci. Lett. 2007, 412, 139-142.

23. Smith, L.; Watson, M.; Gates, S.; Ball, D.; Foxcroft, D. Meta-analysis of the association of the Taq1A polymorphism with the risk of alcohol dependency: a HuGE gene-disease association review. Am. J. Epidemiol. 2008, 167, 125-138.

24. Dal Toso, R.; Sommer, B.; Ewert, M.; Herb, A.; Pritchett, D.B.; Bach, A.; Shivers, B.D.; Seeburg, P.H. The dopamine D2 receptor: two molecular forms generated by alternative splicing. EMBO J. 1989, 8, 4025-4034.

25. Neve, K.A.; Neve, R.L.; Fidel, S.; Janowsky, A.; Higgins, G.A. Increased abundance of alternatively spliced forms of D2 dopamine receptor mRNA after denervation. Proc. Natl. Acad. Sci. U.S.A. 1991, 88, 2802-2806.

26. Khan, Z.U.; Mrzljak, L.; Gutierrez, A.; de la Calle, A.; Goldman-Rakic, P.S. Prominence of the dopamine D2 short isoform in dopaminergic pathways. Proc. Natl. Acad. Sci. U.S.A. 1998, 95, 7731-7736.

27. Usiello, A.; Baik, J.H.; Roug Pont, F.; Picetti, R.; Dierich, A.; LeMeur, M.; Piazza, P.V.; Borrelli, E. Distinct functions of the two isoforms of dopamine D2 receptors. Nature 2000, 408, 199-203.

28. Vile, J.M.; D’Souza, U.M.; Strange, P.G. [3H]nemonapride and [3H]spiperone label equivalent numbers of D2 and D3 dopamine receptors in a range of tissues and under different conditions. $J$. Neurochem. 1995, 64, 940-943.

29. Wang, Y.; Xu, R.; Sasaoka, T.; Tonegawa, S.; Kung, M.P.; Sankoorikal, E.B. Dopamine D2 long receptor-deficient mice display alterations in striatum-dependent functions. J. Neurosci. 2000, 20, 8305-8314.

30. Senogles, S.E. The D2 dopamine receptor isoforms signal through distinct Gi alpha proteins to inhibit adenylyl cyclase. A study with site-directed mutant Gi alpha proteins. J. Biol. Chem. 1994, 269, 23120-23127.

31. Senogles, S.E.; Heimert, T.L.; Odife, E.R.; Quasney, M.W. A region of the third intracellular loop of the short form of the D2 dopamine receptor dictates Gi coupling specificity. J. Biol. Chem. 2004, 279, 1601-1606.

32. Guiramand, J.; Montmayeur, J.P.; Ceraline, J.; Bhatia, M.; Borrelli, E. Alternative splicing of the dopamine D2 receptor directs specificity of coupling to G-proteins. J. Biol. Chem. 1995, 270, 7354-7358. 
33. Lindgren, N.; Usiello, A.; Goiny, M.; Haycock, J.; Erbs, E.; Greengard, P.; Hokfelt, T.; Borrelli, E.; Fisone, G. Distinct roles of dopamine D2L and D2S receptor isoforms in the regulation of protein phosphorylation at presynaptic and postsynaptic sites. Proc. Natl. Acad. Sci. U.S.A. 2003, 100, 4305-4309.

34. Prou, D.; Gu, W. J.; Le Crom, S.; Vincent, J. D.; Salamero, J.; Vernier, P. Intracellular retention of the two isoforms of the $\mathrm{D}(2)$ dopamine receptor promotes endoplasmic reticulum disruption. $J$. Cell Sci. 2001, 114, 3517-3527.

35. Cho, D.I.; Beom, S.; Van Tol, H.H.; Caron, M.G.; Kim, K.M. Characterization of the desensitization properties of five dopamine receptor subtypes and alternatively spliced variants of dopamine D2 and D4 receptors. Biochem. Biophys. Res. Commun. 2006, 350, 634-640.

36. Centonze, D.; Usiello, A.; Gubellini, P.; Pisani, A.; Borrelli, E.; Bernardi, G.; Calabresi, P. Dopamine D2 receptor-mediated inhibition of dopaminergic neurons in mice lacking D2L receptors. Neuropsychopharmacology 2002, 27, 723-726.

37. Xu, R.; Hranilovic, D.; Fetsko, L.A.; Bucan, M.; Wang, Y. Dopamine D2S and D2L receptors may differentially contribute to the actions of antipsychotic and psychotic agents in mice. Mol. Psychiatry 2002, 7, 1075-1082.

38. Hranilovic, D.; Bucan, M.; Wang, Y. Emotional response in dopamine D2L receptor-deficient mice. Behav. Brain Res. 2008, 195, 246-250.

39. Oomizu, S.; Boyadjieva, N.; Sarkar, D.K. Ethanol and estradiol modulate alternative splicing of dopamine D2 receptor messenger RNA and abolish the inhibitory action of bromocriptine on prolactin release from the pituitary gland. Alcohol Clin. Exp. Res. 2003, 27, 975-980.

40. Zhang, Y.; Bertolino, A.; Fazio, L.; Blasi, G.; Rampino, A.; Romano, R.; Lee, M.L.; Xiao, T.; Papp, A.; Wang, D.; Sadee, W. Polymorphisms in human dopamine D2 receptor gene affect gene expression, splicing, and neuronal activity during working memory. Proc. Natl. Acad. Sci. U.S.A. 2007, 104, 20552-20557.

41. Davis, K.M.; Wu, J.Y. Role of glutamatergic and GABAergic systems in alcoholism. J. Biomed. Sci. 2001, 8, 7-19.

42. Grant, K.A.; Lovinger, D.M. Cellular and behavioral neurobiology of alcohol: receptor-mediated neuronal processes. Clin. Neurosci. 1995, 3, 155-164.

43. Wirkner, K.; Poelchen, W.; Koles, L.; Mlberg, K.; Scheibler, P.; Allgaier, C.; Illes, P. Ethanol-induced inhibition of NMDA receptor channels. Neurochem. Int. 1999, 35, 153-162.

44. Ronald, K.M.; Mirshahi, T.; Woodward, J.J. Ethanol inhibition of N-methyl-D-aspartate receptors is reduced by site-directed mutagenesis of a transmembrane domain phenylalanine residue. J. Biol. Chem. 2001, 276, 44729-44735.

45. Follesa, P.; Ticku, M.K. NMDA receptor upregulation: molecular studies in cultured mouse cortical neurons after chronic antagonist exposure. J. Neurosci. 1996, 16, 2172-2178.

46. Hu, X.J.; Follesa, P.; Ticku, M.K. Chronic ethanol treatment produces a selective upregulation of the NMDA receptor subunit gene expression in mammalian cultured cortical neurons. Brain Res. Mol. Brain Res. 1996, 36, 211-218. 
47. Hu, X.J.; Ticku, M.K. Functional characterization of a kindling-like model of ethanol withdrawal in cortical cultured neurons after chronic intermittent ethanol exposure. Brain Res. 1997, 767, 228-234.

48. Trevisan, L.; Fitzgerald, L.W.; Brose, N.; Gasic, G.P.; Heinemann, S.F.; Duman, R.S.; Nestler, E.J. Chronic ingestion of ethanol up-regulates NMDAR1 receptor subunit immunoreactivity in rat hippocampus. J. Neurochem. 1994, 62, 1635-1638.

49. Freund, G.; Anderson, K.J. Glutamate receptors in the frontal cortex of alcoholics. Alcohol Clin. Exp. Res. 1996, 20, 1165-1172.

50. Freund, G.; Anderson, K.J. Glutamate receptors in the cingulate cortex, hippocampus, and cerebellar vermis of alcoholics. Alcohol Clin. Exp. Res. 1999, 23, 1-6.

51. Krystal, J.H.; Petrakis, I.L.; Mason, G.; Trevisan, L.; D’Souza, D.C. N-methyl-D-aspartate glutamate receptors and alcoholism: reward, dependence, treatment, and vulnerability. Pharmacol. Ther. 2003, 99, 79-94.

52. Dunah, A.W.; Yasuda, R.P.; Luo, J.; Wang, Y.; Prybylowski, K.L.; Wolfe, B.B. Biochemical studies of the structure and function of the N-methyl-D-aspartate subtype of glutamate receptors. Mol. Neurobiol. 1999, 19, 151-179.

53. Ciabarra, A.M.; Sullivan, J.M.; Gahn, L.G.; Pecht, G.; Heinemann, S.; Sevarino, K.A. Cloning and characterization of chi-1: a developmentally regulated member of a novel class of the ionotropic glutamate receptor family. J. Neurosci. 1995, 15, 6498-6508.

54. Nishi, M.; Hinds, H.; Lu, H.P.; Kawata, M.; Hayashi, Y. Motoneuron-specific expression of NR3B, a novel NMDA-type glutamate receptor subunit that works in a dominant-negative manner. J. Neurosci. 2001, 21, RC185.

55. Standley, S.; Roche, K.W.; McCallum, J.; Sans, N.; Wenthold, R.J. PDZ domain suppression of an ER retention signal in NMDA receptor NR1 splice variants. Neuron 2000, 28, 887-898.

56. Dingledine, R.; Borges, K.; Bowie, D.; Traynelis, S.F. The glutamate receptor ion channels. Pharmacol. Rev. 1999, 51, 7-61.

57. Laurie, D.J.; Putzke, J.; Zieglgansberger, W.; Seeburg, P.H.; Tolle, T.R. The distribution of splice variants of the NMDAR1 subunit mRNA in adult rat brain. Brain Res. Mol. Brain Res. 1995, 32, 94-108.

58. Durand, G.M.; Gregor, P.; Zheng, X.; Bennett, M.V.; Uhl, G.R.; Zukin, R.S. Cloning of an apparent splice variant of the rat N-methyl-D-aspartate receptor NMDAR1 with altered sensitivity to polyamines and activators of protein kinase C. Proc. Natl. Acad. Sci. U.S.A. 1992, 89, 9359-9363.

59. Traynelis, S.F.; Hartley, M.; Heinemann, S.F. Control of proton sensitivity of the NMDA receptor by RNA splicing and polyamines. Science 1995, 268, 873-876.

60. Traynelis, S.F.; Burgess, M.F.; Zheng, F.; Lyuboslavsky, P.; Powers, J.L. Control of voltage-independent zinc inhibition of NMDA receptors by the NR1 subunit. J. Neurosci. 1998, $18,6163-6175$.

61. Vicini, S.; Wang, J.F.; Li, J.H.; Zhu, W.J.; Wang, Y.H.; Luo, J.H.; Wolfe, B.B.; Grayson, D.R. Functional and pharmacological differences between recombinant N-methyl-D-aspartate receptors. J. Neurophysiol. 1998, 79, 555-566. 
62. Rumbaugh, G.; Prybylowski, K.; Wang, J.F.; Vicini, S. Exon 5 and spermine regulate deactivation of NMDA receptor subtypes. J. Neurophysiol. 2000, 83, 1300-1306.

63. Ehlers, M.D.; Zhang, S.; Bernhadt, J.P.; Huganir, R.L. Inactivation of NMDA receptors by direct interaction of calmodulin with the NR1 subunit. Cell 1996, 84, 745-755.

64. Rycroft, B.K.; Gibb, A.J. Regulation of single NMDA receptor channel activity by alpha-actinin and calmodulin in rat hippocampal granule cells. J. Physiol.2004, 557, 795-808.

65. Ataman, Z.A.; Gakhar, L.; Sorensen, B.R.; Hell, J.W.; Shea, M.A. The NMDA receptor NR1 C1 region bound to calmodulin: structural insights into functional differences between homologous domains. Structure 2007, 15, 1603-1617.

66. Ehlers, M.D.; Tingley, W.G.; Huganir, R.L. Regulated subcellular distribution of the NR1 subunit of the NMDA receptor. Science 1995, 269, 1734-1737.

67. Zheng, X.; Zhang, L.; Wang, A.P.; Bennett, M.V.; Zukin, R.S. Protein kinase C potentiation of Nmethyl-D-aspartate receptor activity is not mediated by phosphorylation of N-methyl-D-aspartate receptor subunits. Proc. Natl. Acad. Sci. U.S.A. 1999, 96, 15262-15267.

68. Lan, J.Y.; Skeberdis, V.A.; Jover, T.; Grooms, S.Y.; Lin, Y.; Araneda, R.C.; Zheng, X.; Bennett, M.V.; Zukin, R.S. Protein kinase C modulates NMDA receptor trafficking and gating. Nat. Neurosci. 2001, 4, 382-390.

69. Koltchine, V.; Anantharam, V.; Wilson, A.; Bayley, H.; Treistman, S.N. Homomeric assemblies of NMDAR1 splice variants are sensitive to ethanol. Neurosci. Lett. 1993, 152, 13-16.

70. Jin, C.; Woodward, J.J. Effects of 8 different NR1 splice variants on the ethanol inhibition of recombinant NMDA receptors. Alcohol Clin. Exp. Res. 2006, 30, 673-679.

71. Winkler, A.; Mahal, B.; Kiianmaa, K.; Zieglgansberger, W.; Spanagel, R. Effects of chronic alcohol consumption on the expression of different NR1 splice variants in the brain of AA and ANA lines of rats. Brain. Res. Mol. Brain Res. 1999, 72, 166-175.

72. Hardy, P.A.; Chen, W.; Wilce, P.A. Chronic ethanol exposure and withdrawal influence NMDA receptor subunit and splice variant mRNA expression in the rat cerebral cortex. Brain Res. 1999, 819, 33-39.

73. Kumari, M. Differential effects of chronic ethanol treatment on N-methyl-D-aspartate R1 splice variants in fetal cortical neurons. J. Biol. Chem. 2001, 276, 29764-29771.

74. Nagy, J.; Kolok, S.; Dezso, P.; Boros, A.; Szombathelyi, Z. Differential alterations in the expression of NMDA receptor subunits following chronic ethanol treatment in primary cultures of rat cortical and hippocampal neurones. Neurochem. Int. 2003, 42, 35-43.

75. Honse, Y.; Nixon, K.M.; Browning, M.D.; Leslie, S.W. Cell surface expression of NR1 splice variants and NR2 subunits is modified by prenatal ethanol exposure. Neuroscience 2003, 122, 689-698.

76. Zhou, F.C.; Anthony, B.; Dunn, K.W.; Lindquist, W.B.; Xu, Z.C.; Deng, P. Chronic alcohol drinking alters neuronal dendritic spines in the brain reward center nucleus accumbens. Brain Res. 2007, 1134, 148-161.

77. Raeder, H.; Holter, S.M.; Hartmann, A.M.; Spanagel, R.; Moller, H.J.; Rujescu, D. Expression of $\mathrm{N}$-methyl-d-aspartate (NMDA) receptor subunits and splice variants in an animal model of long-term voluntary alcohol self-administration. Drug Alcohol Depend. 2008, 96, 16-21. 
78. Lobo, I.A.; Harris, R.A. GABA(A) receptors and alcohol. Pharmacol. Biochem. Behav.2008, 90, 90-94.

79. Morrow, A.L.; Montpied, P.; Lingford-Hughes, A.; Paul, S.M. Chronic ethanol and pentobarbital administration in the rat: effects on GABAA receptor function and expression in brain. Alcohol 1990, 7, 237-244.

80. Wan, F.J.; Berton, F.; Madamba, S.G.; Francesconi, W.; Siggins, G.R. Low ethanol concentrations enhance GABAergic inhibitory postsynaptic potentials in hippocampal pyramidal neurons only after block of GABAB receptors. Proc. Natl. Acad. Sci. U.S.A.1996, 93, 5049-5054.

81. Kumar, S.; Porcu, P.; Werner, D.F.; Matthews, D.B.; Diaz-Granados, J.L.; Helfand, R.S.; Morrow, A.L. The role of GABA(A) receptors in the acute and chronic effects of ethanol: a decade of progress. Psychopharmacology (Berl) 2009, 205, 529-564.

82. Mihic, S.J.; Ye, Q.; Wick, M.J.; Koltchine, V.V.; Krasowski, M.D.; Finn, S.E.; Mascia, M.P.; Valenzuela, C.F.; Hanson, K.K.; Greenblatt, E.P.; Harris, R.A.; Harrison, N.L. Sites of alcohol and volatile anaesthetic action on GABA(A) and glycine receptors. Nature 1997, 389, 385-389.

83. Mascia, M.P.; Trudell, J.R.; Harris, R.A. Specific binding sites for alcohols and anesthetics on ligand-gated ion channels. Proc. Natl. Acad. Sci. U.S.A. 2000, 97, 9305-9310.

84. Jung, S.; Harris, R.A. Sites in TM2 and 3 are critical for alcohol-induced conformational changes in GABA receptors. J. Neurochem.2006, 96, 885-892.

85. Gallegos, R.A.; Lee, R.S.; Criado, J.R.; Henriksen, S.J.; Steffensen, S.C. Adaptive responses of gamma-aminobutyric acid neurons in the ventral tegmental area to chronic ethanol. J. Pharmacol. Exp. Ther. 1999, 291, 1045-1053.

86. Xiao, C.; Ye, J.H. Ethanol dually modulates GABAergic synaptic transmission onto dopaminergic neurons in ventral tegmental area: role of mu-opioid receptors. Neuroscience 2008, 153, 240-248.

87. Margolis, E.B.; Fields, H.L.; Hjelmstad, G.O.; Mitchell, J.M. Delta-opioid receptor expression in the ventral tegmental area protects against elevated alcohol consumption. J. Neurosci. 2008, 28, 12672-12681.

88. Michels, G.; Moss, S.J. GABAA receptors: properties and trafficking. Crit. Rev. Biochem. Mol. Biol. 2007, 42, 3-14.

89. Boyle, A.E.; Segal, R.; Smith, B.R.; Amit, Z. Bidirectional effects of GABAergic agonists and antagonists on maintenance of voluntary ethanol intake in rats. Pharmacol. Biochem. Behav. 1993, $46,179-182$.

90. Nowak, K.L.; McBride, W.J.; Lumeng, L.; Li, T.K.; Murphy, J.M. Blocking GABA(A) receptors in the anterior ventral tegmental area attenuates ethanol intake of the alcohol-preferring $\mathrm{P}$ rat. Psychopharmacology (Berl) 1998, 139, 108-116.

91. Tomkins, D.M.; Fletcher, P.J. Evidence that GABA(A) but not GABA(B) receptor activation in the dorsal raphe nucleus modulates ethanol intake in Wistar rats. Behav. Pharmacol. 1996, 7, 85-93.

92. Tian, H.; Chen, H.J.; Cross, T.H.; Edenberg, H.J. Alternative splicing and promoter use in the human GABRA2 gene. Brain Res. Mol. Brain Res. 2005, 137, 174-183.

93. Enoch, M.A. The role of GABA(A) receptors in the development of alcoholism. Pharmacol. Biochem. Behav. 2008, 90, 95-104. 
94 Edenberg, H.J.; Dick, D.M.; Xuei, X.; Tian, H.; Almasy, L.; Bauer, L.O.; Crowe, R.R.; Goate, A.; Hesselbrock, V.; Jones, K.; Kwon, J.; Li, T.K.; Nurnberger, J.I. Jr.; O'Connor, S.J.; Reich, T.; Rice, J.; Schuckit, M.A.; Porjesz, B.; Foroud, T.; Begleiter, H. Variations in GABRA2, encoding the alpha 2 subunit of the $\operatorname{GABA}(\mathrm{A})$ receptor, are associated with alcohol dependence and with brain oscillations. Am. J. Hum. Genet. 2004, 74, 705-714.

95. Petrie, J.; Sapp, D.W.; Tyndale, R.F.; Park, M.K.; Fanselow, M.; Olsen, R.W. Altered gabaa receptor subunit and splice variant expression in rats treated with chronic intermittent ethanol. Alcohol Clin. Exp. Res. 2001, 25, 819-828.

96. Krishek, B.J.; Xie, X.; Blackstone, C.; Huganir, R.L.; Moss, S.J.; Smart, T.G. Regulation of GABAA receptor function by protein kinase C phosphorylation. Neuron 1994, 12, 1081-1095.

97. Wafford, K.A.; Burnett, D.M.; Leidenheimer, N.J.; Burt, D.R.; Wang, J.B.; Kofuji, P.; Dunwiddie, T.V.; Harris, R.A.; Sikela, J.M. Ethanol sensitivity of the GABAA receptor expressed in Xenopus oocytes requires 8 amino acids contained in the gamma 2L subunit. Neuron 1991, 7, 27-33.

98. Benkwitz, C.; Banks, M.I.; Pearce, R.A. Influence of GABAA receptor gamma2 splice variants on receptor kinetics and isoflurane modulation. Anesthesiology 2004, 101, 924-936.

99. Homanics, G.E.; Harrison, N.L.; Quinlan, J.J.; Krasowski, M.D.; Rick, C.E.; de Blas, A.L.; Mehta, A.K.; Kist, F.; Mihalek, R.M.; Aul, J.J.; Firestone, L.L. Normal electrophysiological and behavioral responses to ethanol in mice lacking the long splice variant of the gamma2 subunit of the gamma-aminobutyrate type A receptor. Neuropharmacology 1999, 38, 253-265.

100. Meier, J.; Grantyn, R. Preferential accumulation of GABAA receptor gamma 2L, not gamma 2S, cytoplasmic loops at rat spinal cord inhibitory synapses. J. Physiol. 2004, 559, 355-365.

101. Roberts, A.A.; Kellogg, C.K. Synchronous postnatal increase in alpha1 and gamma2L GABA(A) receptor mRNAs and high affinity zolpidem binding across three regions of rat brain. Brain Res. Dev. Brain Res. 2000, 119, 21-32.

102. Solem, M.; McMahon, T.; Messing, R.O. Protein kinase A regulates regulates inhibition of N- and P/Q-type calcium channels by ethanol in PC12 cells. J. Pharmacol. Exp. Ther. 1997, 282, 1487-1495.

103. McMahon, T.; Andersen, R.; Metten, P.; Crabbe, J.C.; Messing, R.O. Protein kinase C epsilon mediates up-regulation of N-type calcium channels by ethanol. Mol. Pharmacol. 2000, 57, 53-58.

104. Newton, P.M.; Orr, C.J.; Wallace, M.J.; Kim, C.; Shin, H.S.; Messing, R.O. Deletion of N-type calcium channels alters ethanol reward and reduces ethanol consumption in mice. J. Neurosci. 2004, 24, 9862-9869.

105. Newton, P.M.; Zeng, L.; Wang, V.; Connolly, J.; Wallace, M.J.; Kim, C.; Shin, H.S.; Belardetti, F.; Snutch, T.P.; Messing, R.O. A Blocker of N- and T-type Voltage-Gated Calcium Channels Attenuates Ethanol-Induced Intoxication, Place Preference, Self-Administration, and Reinstatement. J. Neurosci. 2008, 28, 11712-11719.

106. Lin, Z.; Harris, C.; Lipscombe, D. The molecular identity of Ca channel alpha 1-subunits expressed in rat sympathetic neurons. J. Mol. Neurosci. 1996, 7, 257-267.

107. Lin, Z.; Haus, S.; Edgerton, J.; Lipscombe, D. Identification of functionally distinct isoforms of the N-type Ca2+ channel in rat sympathetic ganglia and brain. Neuron 1997, 18, 153-166. 
108. Newton, P.M.; Tully, K.; McMahon, T.; Connolly, J.; Dadgar, J.; Treistman, S.N.; Messing, R.O. Chronic ethanol exposure induces an N-type calcium channel splice variant with altered channel kinetics. FEBS Lett. 2005, 579, 671-676.

109. Wang, X.; Wang, G.; Lemos, J.R.; Treistman, S.N. Ethanol directly modulates gating of a dihydropyridine-sensitive Ca2+ channel in neurohypophysial terminals. J. Neurosci. 1994, 14, 5453-5460.

110. Grant, A.J.; Koski, G.; Treistman, S.N. Effect of chronic ethanol on calcium currents and calcium uptake in undifferentiated PC12 cells. Brain Res. 1993, 600, 280-284.

111. Little, H.J.; Dolin, S.J.; Halsey, M.J. Calcium channel antagonists decrease the ethanol withdrawal syndrome. Life Sci. 1986, 39, 2059-2065.

112. Rezvani, A.H.; Janowsky, D.S. Decreased alcohol consumption by verapamil in alcohol preferring rats. Prog. Neuropsychopharmacol. Biol. Psychiatry 1990, 14, 623-631.

113. Snutch, T.P.; Tomlinson, W.J.; Leonard, J.P.; Gilbert, M.M. Distinct calcium channels are generated by alternative splicing and are differentially expressed in the mammalian CNS. Neuron 1991, 7, 45-57.

114. Walter, H.J.; McMahon, T.; Dadgar, J.; Wang, D.; Messing, R.O. Ethanol regulates calcium channel subunits by protein kinase $\mathrm{C}$ delta -dependent and -independent mechanisms. J. Biol. Chem. 2000, 275, 25717-25722.

115. Sah, P.; Faber, E.S. Channels underlying neuronal calcium-activated potassium currents. Prog. Neurobiol. 2002, 66, 345-353.

116. Cui, J.; Yang, H.; Lee, U.S. Molecular mechanisms of BK channel activation. Cell Mol. Life Sci. 2009, 66, 852-875.

117. Dopico, A.M.; Lemos, J.R.; Treistman, S.N. Ethanol increases the activity of large conductance, $\mathrm{Ca}(2+)$-activated $\mathrm{K}+$ channels in isolated neurohypophysial terminals. Mol. Pharmacol. 1996, 49, 40-48.

118. Pietrzykowski, A.Z.; Martin, G.E.; Puig, S.I.; Knott, T.K.; Lemos, J.R.; Treistman, S.N. Alcohol tolerance in large-conductance, calcium-activated potassium channels of CNS terminals is intrinsic and includes two components: decreased ethanol potentiation and decreased channel density. J. Neurosci. 2004, 24, 8322-8332.

119. Jakab, M.; Weiger, T.M.; Hermann, A. Ethanol activates maxi Ca2+-activated K+ channels of clonal pituitary (GH3) cells. J. Membr. Biol. 1997, 157, 237-245.

120. Gruss, M.; Henrich, M.; Konig, P.; Hempelmann, G.; Vogel, W.; Scholz, A. Ethanol reduces excitability in a subgroup of primary sensory neurons by activation of $\mathrm{BK}(\mathrm{Ca})$ channels. Eur. J. Neurosci. 2001, 14, 1246-1256.

121. Dopico, A.M. Ethanol sensitivity of $\mathrm{BK}(\mathrm{Ca})$ channels from arterial smooth muscle does not require the presence of the beta 1-subunit. Am. J. Physiol. Cell Physiol. 2003, 284, C1468-1480.

122. Walters, F.S.; Covarrubias, M.; Ellingson, J.S. Potent inhibition of the aortic smooth muscle maxi-K channel by clinical doses of ethanol. Am. J. Physiol. Cell Physiol. 2000, 279, C1107-1115. 
123. Martin, G.; Puig, S.; Pietrzykowski, A.; Zadek, P.; Emery, P.; Treistman, S. Somatic localization of a specific large-conductance calcium-activated potassium channel subtype controls compartmentalized ethanol sensitivity in the nucleus accumbens. J. Neurosci. 2004, 24, 65636572.

124. Liu, J.; Asuncion-Chin, M.; Liu, P.; Dopico, A.M. CaM kinase II phosphorylation of slo Thr107 regulates activity and ethanol responses of BK channels. Nat. Neurosci. 2006, 9, 41-49.

125. Crowley, J.J.; Treistman, S.N.; Dopico, A.M. Cholesterol antagonizes ethanol potentiation of human brain BKCa channels reconstituted into phospholipid bilayers. Mol. Pharmacol. 2003, 64, 365-372.

126. Crowley, J.J.; Treistman, S.N.; Dopico, A.M. Distinct structural features of phospholipids differentially determine ethanol sensitivity and basal function of BK channels. Mol. Pharmacol. 2005, 68, 4-10.

127. Yuan, C.; O'Connell, R.J.; Wilson, A.; Pietrzykowski, A.Z.; Treistman, S.N. Acute alcohol tolerance is intrinsic to the $\mathrm{BKCa}$ protein, but is modulated by the lipid environment. J. Biol. Chem. 2008, 283, 5090-5098.

128. Martin, G.E.; Hendrickson, L.M.; Penta, K.L.; Friesen, R.M.; Pietrzykowski, A.Z.; Tapper, A.R.; Treistman, S.N. Identification of a BK channel auxiliary protein controlling molecular and behavioral tolerance to alcohol. Proc. Natl. Acad. Sci. U.S.A. 2008, 105, 17543-17548.

129. Pietrzykowski, A.Z.; Friesen, R.M.; Martin, G.E.; Puig, S.I.; Nowak, C.L.; Wynne, P.M.; Siegelmann, H.T.; Treistman, S.N. Posttranscriptional regulation of BK channel splice variant stability by miR-9 underlies neuroadaptation to alcohol. Neuron 2008, 59, 274-287.

130. Charness, M.E.; Safran, R.M.; Perides, G. Ethanol inhibits neural cell-cell adhesion. J. Biol. Chem. 1994, 269, 9304-9309.

131. Bearer, C.F.; Swick, A.R.; O'Riordan, M.A.; Cheng, G. Ethanol inhibits L1-mediated neurite outgrowth in postnatal rat cerebellar granule cells. J. Biol. Chem. 1999, 274, 13264-13270.

132. Arevalo, E.; Shanmugasundararaj, S.; Wilkemeyer, M.F.; Dou, X.; Chen, S.; Charness, M.E.; Miller, K.W. An alcohol binding site on the neural cell adhesion molecule L1. Proc. Natl. Acad. Sci. U.S.A. 2008, 105, 371-375.

133. Yeaney, N.K.; He, M.; Tang, N.; Malouf, A.T.; O'Riordan, M.A.; Lemmon, V.; Bearer, C.F. Ethanol inhibits L1 cell adhesion molecule tyrosine phosphorylation and dephosphorylation and activation of pp60(src). J. Neurochem. 2009, 110, 779-790.

134. Craig, A.M.; Kang, Y. Neurexin-neuroligin signaling in synapse development. Curr. Opin. Neurobiol. 2007, 17, 43-52.

135. Graf, E.R.; Zhang, X.; Jin, S.X.; Linhoff, M.W.; Craig, A.M. Neurexins induce differentiation of GABA and glutamate postsynaptic specializations via neuroligins. Cell 2004, 119, 1013-1026.

136. Missler, M.; Zhang, W.; Rohlmann, A.; Kattenstroth, G.; Hammer, R.E.; Gottmann, K.; Shof, T.C. Alpha-neurexins couple Ca2+ channels to synaptic vesicle exocytosis. Nature 2003, 423, 939-948.

137. Zhang, W.; Rohlmann, A.; Sargsyan, V.; Aramuni, G.; Hammer, R.E.; Shof, T.C.; Missler, M. Extracellular domains of alpha-neurexins participate in regulating synaptic transmission by selectively affecting N- and P/Q-type Ca2+ channels. J. Neurosci. 2005, 25, 4330-4342. 
138. Dudanova, I.; Sedej, S.; Ahmad, M.; Masius, H.; Sargsyan, V.; Zhang, W.; Riedel, D.; Angenstein, F.; Schild, D.; Rupnik, M.; Missler, M. Important contribution of alpha-neurexins to Ca2+triggered exocytosis of secretory granules. J. Neurosci. 2006, 26, 10599-10613.

139. Bierut, L.J.; Madden, P.A.; Breslau, N.; Johnson, E.O.; Hatsukami, D.; Pomerleau, O.F.; Swan, G.E.; Rutter, J.; Bertelsen, S.; Fox, L.; Fugman, D.; Goate, A.M.; Hinrichs, A.L.; Konvicka, K.; Martin, N.G.; Montgomery, G.W.; Saccone, N.L.; Saccone, S.F.; Wang, J.C.; Chase, G.A.; Rice, J.P.; Ballinger, D.G. Novel genes identified in a high-density genome wide association study for nicotine dependence. Hum. Mol. Genet. 2007, 16, 24-35.

140. Nussbaum, J.; Xu, Q.; Payne, T.J.; Ma, J.Z.; Huang, W.; Gelernter, J.; Li, M.D. Significant association of the neurexin-1 gene (NRXN1) with nicotine dependence in European- and AfricanAmerican smokers. Hum. Mol. Genet. 2008, 17, 1569-1577.

141. Lachman, H.M.; Fann, C.S.; Bartzis, M.; Evgrafov, O.V.; Rosenthal, R.N.; Nunes, E.V.; Miner, C.; Santana, M.; Gaffney, J.; Riddick, A.; Hsu, C.L.; Knowles, J.A. Genomewide suggestive linkage of opioid dependence to chromosome 14q. Hum. Mol. Genet. 2007, 16, 1327-1334.

142. Liu, Q.R.; Drgon, T.; Walther, D.; Johnson, C.; Poleskaya, O.; Hess, J.; Uhl, G.R. Pooled association genome scanning: validation and use to identify addiction vulnerability loci in two samples. Proc. Natl. Acad. Sci. U.S.A. 2005, 102, 11864-11869.

143. Kelai, S.; Maussion, G.; Noble, F.; Boni, C.; Ramoz, N.; Moalic, J.M.; Peuchmaur, M.; Gorwood, P.; Simonneau, M. Nrxn3 upregulation in the globus pallidus of mice developing cocaine addiction. Neuroreport 2008, 19, 751-755.

144. Lein, E.S.; Hawrylycz, M.J.; Ao, N.; Ayres, M.; Bensinger, A.; Bernard, A.; Boe, A.F.; Boguski, M.S.; Brockway, K.S.; Byrnes, E.J.; Chen, L.; Chen, T.M.; Chin, M.C.; Chong, J.; Crook, B.E.; Czaplinska, A.; Dang, C.N.; Datta, S.; Dee, N.R.; Desaki, A.L.; Desta, T.; Diep, E.; Dolbeare, T.A.; Donelan, M.J.; Dong, H.W.; Dougherty, J.G.; Duncan, B.J.; Ebbert, A.J.; Eichele, G.; Estin, L.K.; Faber, C.; Facer, B.A.; Fields, R.; Fischer, S.R.; Fliss, T.P.; Frensley, C.; Gates, S.N.; Glattfelder, K.J.; Halverson, K.R.; Hart, M.R.; Hohmann, J.G.; Howell, M.P.; Jeung, D.P.; Johnson, R.A.; Karr, P.T.; Kawal, R.; Kidney, J.M.; Knapik, R.H.; Kuan, C.L.; Lake, J.H.; Laramee, A.R.; Larsen, K.D.; Lau, C.; Lemon, T.A.; Liang, A.J.; Liu, Y.; Luong, L.T.; Michaels, J.; Morgan, J.J.; Morgan, R.J.; Mortrud, M.T.; Mosqueda, N.F.; Ng, L.L.; Ng, R.; Orta, G.J.; Overly, C.C.; Pak, T.H.; Parry, S.E.; Pathak, S.D.; Pearson, O.C.; Puchalski, R.B.; Riley, Z.L.; Rockett, H.R.; Rowland, S.A.; Royall, J.J.; Ruiz, M.J.; Sarno, N.R.; Schaffnit, K.; Shapovalova, N.V.; Sivisay, T.; Slaughterbeck, C.R.; Smith, S.C.; Smith, K.A.; Smith, B.I.; Sodt, A.J.; Stewart, N.N.; Stumpf, K.R.; Sunkin, S.M.; Sutram, M.; Tam, A.; Teemer, C.D.; Thaller, C.; Thompson, C.L.; Varnam, L.R.; Visel, A.; Whitlock, R.M.; Wohnoutka, P.E.; Wolkey, C.K.; Wong, V.Y.; Wood, M.; et al. Genome-wide atlas of gene expression in the adult mouse brain. Nature 2007, 445, 168-176.

145. Chih, B.; Gollan, L.; Scheiffele, P. Alternative splicing controls selective trans-synaptic interactions of the neuroligin-neurexin complex. Neuron 2006, 51, 171-178.

146. Boucard, A.A.; Chubykin, A.A.; Comoletti, D.; Taylor, P.; S - hof, T.C. A splice code for trans-synaptic cell adhesion mediated by binding of neuroligin 1 to alpha- and beta-neurexins. Neuron 2005, 48, 229-236. 
147. Hishimoto, A.; Liu, Q.R.; Drgon, T.; Pletnikova, O.; Walther, D.; Zhu, X.G.; Troncoso, J.C.; Uhl, G.R. Neurexin 3 polymorphisms are associated with alcohol dependence and altered expression of specific isoforms. Hum. Mol. Genet. 2007, 16, 2880-2891.

148. Albano, E. Alcohol, oxidative stress and free radical damage. Proc. Nutr. Soc. 2006, 65, 278-290.

149. Biamonti, G.; Caceres, J.F. Cellular stress and RNA splicing. Trends Biochem. Sci. 2009, 34, 146-153.

150. Castle, J.C.; Zhang, C.; Shah, J.K.; Kulkarni, A.V.; Kalsotra, A.; Cooper, T.A.; Johnson, J.M. Expression of 24,426 human alternative splicing events and predicted cis regulation in 48 tissues and cell lines. Nat. Genet. 2008, 40, 1416-1425.

(C) 2010 by the authors; licensee Molecular Diversity Preservation International, Basel, Switzerland. This article is an open-access article distributed under the terms and conditions of the Creative Commons Attribution license (http://creativecommons.org/licenses/by/3.0/). 